\title{
PERBANDINGAN METODE UJI GULA PEREDUKSI DALAM PENENTUAN AKTIVITAS $\alpha$-L-ARABINOFURANOSIDASE DENGAN SUBSTRAT JANUR KELAPA (COCOS NUCIFERA)
}

\author{
Y. H. Pratiwi, O. Ratnayani, dan I N. Wirajana*
}

Progam Studi Kimia, Fakultas Matematika dan Ilmu Pengetahuan Alam, Universitas Udayana *Email: nengah_wirajana@unud.ac.id

\begin{abstract}
ABSTRAK
Pengujian gula pereduksi umumnya dilakukan dengan reagen asam 2,3-dinitrosalisilat (DNS) dan Nelson-Somogyi (NS) dalam penentuan aktivitas enzim pendegradasi polisakarida. Tujuan penelitian ini adalah untuk membandingkan metode uji gula pereduksi DNS dan NS dalam penentuan aktivitas $\alpha$-LArabinofuranosidase (AbfA) termostabil, dengan substrat janur kelapa (Cocos nucifera). Enzim AbfA diperoleh dari Saccharomyces cerevisiae rekombinan yang dikultivasi selama 3 hari pada suhu inkubasi $30{ }^{\circ} \mathrm{C}$. Penentuan aktivitas enzim AbfA dilakukan pada kondisi pH 6, suhu $70{ }^{\circ} \mathrm{C}$ dan waktu inkubasi 15 menit. Hasil penelitian menunjukkan bahwa penentuan aktivitas enzim AbfA dengan metode NS lebih teliti atau memiliki standar deviasi yang jauh lebih kecil dibandingkan dengan metode DNS, namun kurva kalibrasi larutan standar metode DNS lebih linear dibandingkan metode NS.
\end{abstract}

Kata kunci : $\alpha$-L-Arabinofuranosidase, 3,5-dinitrosalisilat (DNS), Nelson-Somogyi (NS).

\begin{abstract}
The 3,5-dinitrosalicylic acid (DNS) and Nelson-Somogyi (NS) assays for reducing sugars are commonly used to measure the activity of polysaccharide degrading enzymes. The aim of this study was to compare the DNS and NS assay methods for reducing sugars for the determination of thermostable $\alpha$-Larabinofuranosidase (AbfA) activity, with substrate of the young coconut leaf (Cocos nucifera). The AbfA enzyme was obtained from recombinant $S$. cerevisiae which cultivated for 3 days at $30{ }^{\circ} \mathrm{C}$ incubation temperature. The measurement of the AbfA enzyme activity was made under under the following conditions, namely $\mathrm{pH} 6$, temperature $70{ }^{\circ} \mathrm{C}$ and incubation time 15 minutes. The research results showed that the measurement of the AbfA enzyme activity with the NS method was more accurate or the standard deviation much smaller than the DNS method, but the standard solution calibration curve of the DNS method was more linear than the NS method.
\end{abstract}

Keywords : $\alpha$-L-Arabinofuranosidase, 3,5-dinitrosalicylic (DNS), Nelson-Somogyi (NS)

\section{PENDAHULUAN}

Hemiselulase diaplikasikan dalam proses sakarifikasi, peningkatan kualitas kertas, industri obat dan degradasi limbah pertanian (Liao et al., 2014; Patel et al., 2015). Enzim $\alpha$-L-arabinofuranosidase (EC 3.2.1.55) merupakan salah satu hemiselulase yang berperan dalam biokonversi lignoselulosa menjadi oligosakarida dan monosakaridanya. Enzim ini merupakan ekso enzim yang dapat memotong ikatan pada ujung non-pereduksi $\alpha$ L-1,2-, $\alpha$-L-1,3- dan $\alpha$-L-1,5-arabinofuranosidik serta berperan pada hidrolisis substrat oligosakarida dan polisakarida. Penelitian tentang $\alpha$-L-arabinofuranosidase ini diperlukan karena berperan penting sebagai enzim kunci pendegradasi xilan dalam hemiselulosa, sehingga banyak diteliti dalam beberapa tahun belakangan (Patel, et al., 2015).

Gen penyandi $\alpha$-L-arabinofuranosidase termostabil yang berasal dari bakteri Geobacillus thermoleovorans IT-08 telah berhasil diklon ke sel inang Escherichia coli DH5 $\alpha /$ pTP510 (Puspaningsih, 2004). Studi selanjutnya, gen $\alpha$-L-arabinofuranosidase termostabil dalam sel inang E. coli $\mathrm{DH} 5 \alpha /$ pTP510 disubkloning ke dalam sel inang ragi Saccharomyces cerevisiae strain BJ1824. Ragi rekombinan tersebut diberi nama $S$. cerevisiae BJ1824/pYHM1-Af, sedangkan $\alpha$-L-arabinofuranosidase yang dihasilkan dari $S$. cerevisiae rekombinan tersebut selanjutnya 
Perbandingan Metode Uji Gula Pereduksi dalam Penentuan

Aktivitas $\alpha$-L-Arabinofuranosidase dengan Substrat Janur Kelapa (Cocos nucifera) (Y. H. Pratiwi, O. Ratnayani, dan I N. Wirajana)

diberi nama enzim AbfA (Wirajana et al., 2016).

Janur kelapa (Cocos nucifera) mengandung hemiselulosa $19,27 \%$ (Tirono, 2011), yang limbahnya banyak ditemukan di Bali. Enzim AbfA sebagai salah satu hemiselulase diduga memiliki aktivitas terhadap substrat hemiselulosa dalam janur kelapa. Penentuan aktivitas enzim AbfA dengan subtrat janur kelapa perlu dilakukan untuk mengetahui potensi enzim ini dalam degradasi limbah biomassa yang ramah lingkungan.

Penentuan aktivitas enzim AbfA dilakukan berdasarkan kemampuan enzim tersebut dalam mengurai substrat, yang dalam penelitian ini adalah polisakarida hemiselulosa dalam janur kelapa menjadi struktur hemiselulosa yang terdegradasi dan monosakarida dalam bentuk gula pereduksi pada satuan waktu tertentu. Metode yang paling sering digunakan dalam penentuan gula pereduksi produk reaksi enzimatis dari enzimenzim pendegradasi polisakarida adalah metode Bailey (1992). Metode ini menggunakan reagen asam 3,5- dinitrosalisilat (DNS). Metode DNS prinsipnya adalah gula pereduksi akan bereaksi dengan reagen DNS membentuk senyawa asam 3-amino-5nitrosalisilat yang berwarna kuning kecoklatan. Metode lain yang digunakan dalam penetuan gula pereduksi adalah metode klasik Nelson-Somogyi (NS) yang menggunakan arsen molibdat dalam penggunaanya. Metode NS memiliki prinsip gula pereduksi dalam sampel akan mereduksi ion $\mathrm{Cu}^{2+}$ menjadi ion $\mathrm{Cu}^{+}$ketika dipanaskan. Ion $\mathrm{Cu}^{+}$yang terbentuk akan mereduksi senyawa arsen molibdat membentuk kompleks berwarna biru kehijauan (Somogyi, 1952).

Metode NS memiliki harga pereaksinya yang lebih murah dibandingkan dengan DNS dan belum pernah digunakan dalam pengukuran aktivitas enzim AbfA. Penelitian ini bertujuan untuk untuk membandingkan metode DNS dan NS dalam penentuan aktivitas $\alpha$-L-arabinofuranosidase termostabil dari $S$. cerevisiae rekombinan dengan substrat janur kelapa (Cocos nucifera).

\section{MATERI DAN METODE}

\section{Bahan}

Bahan-bahan kimia yang digunakan antara lain: 3,5-Dinitrosalicylic acid (DNS), natrium hidroksida $(\mathrm{NaOH})$, kalium natrium tartrat $\left(\mathrm{C}_{4} \mathrm{H}_{4} \mathrm{KNaO}_{6} .4 \mathrm{H}_{2} \mathrm{O}\right)$, fenol, natrium bikarbonat $\left(\mathrm{NaHCO}_{3}\right)$, natrium sulfat anhidrat $\left(\mathrm{Na}_{2} \mathrm{SO}_{4}\right)$, tembaga (II) sulfat pentahidrat $\left(\mathrm{CuSO}_{4} .5 \mathrm{H}_{2} \mathrm{O}\right)$, asam sulfat pekat $\left(\mathrm{H}_{2} \mathrm{SO}_{4}\right)$, ammonium molibdat tetrahidrat $\left(\left(\mathrm{NH}_{4}\right)_{6} \mathrm{Mo}_{7} \mathrm{O}_{24} \cdot 4 \mathrm{H}_{2} \mathrm{O}\right)$, di-natrium arsenat heptahidrat $\left(\mathrm{Na}_{2} \mathrm{HAsO}_{4} \cdot 7 \mathrm{H}_{2} \mathrm{O}\right)$. Bahan-bahan untuk media ragi : yeast nitrogen base without amino acids (YNB), histidin, leusin, triptofan, yeast extract, bacto-peptone, dekstrosa, bactoagar, laktosa, janur kelapa (Cocos nucifera) yang berasal dari limbah canang.

\section{Peralatan}

Spektrofotometer UV-Vis (Thermo Scientific Genesys), pH meter, inkubator, hot plate stirer, inkubator shaker, autoclave, mikro sentrifugasi, laminar air flow cabinet, spatula, mikro pipet, tip kuning $(200 \mu \mathrm{L})$, tip biru $(1000 \mu \mathrm{L})$, tabung mikro 1,5 mL (Eppendorf), alat-alat gelas, jarum ose dan neraca analitik.

\section{CARA KERJA \\ Produksi Enzim AbfA}

S. cerevisiae rekombinan dari stok gliserol diremajakan pada media padat YNBD (yeast nitrogen base without amino acids $0,67 \% \mathrm{~b} / \mathrm{v}$, histidin, leusin, triptofan, dekstrosa $1 \% \mathrm{~b} / \mathrm{v}$, dan bacto-agar $2 \% \mathrm{~b} / \mathrm{v})$ dan diinkubasi selama 3 hari pada suhu $30^{\circ} \mathrm{C}$. Koloni tunggal yang tumbuh dipindahkan ke media cair YPD (yeast extract $1 \% \mathrm{~b} / \mathrm{v}$, bactopeptone $2 \% \mathrm{~b} / \mathrm{v}$, dan dekstrosa $2 \% \mathrm{~b} / \mathrm{v}$ ) dan dikultivasi selama 2 hari pada suhu $30^{\circ} \mathrm{C}$ serta digoyang dengan shaker pada kecepatan 120 rpm. Selanjutnya $200 \mu \mathrm{L}$ kultur sel yang tumbuh dipindahkan ke media cair YPDL (yeast extract $1 \% \mathrm{~b} / \mathrm{v}$, bacto-peptone $2 \% \mathrm{~b} / \mathrm{v}$, bacto-agar $2 \% \mathrm{~b} / \mathrm{v}$, dekstrosa $1 \% \mathrm{~b} / \mathrm{v}$, dan laktosa $1 \% \mathrm{~b} / \mathrm{v}$ ) dan dikultivasi selama 4 hari pada suhu $30^{\circ} \mathrm{C}$ serta digoyang dengan shaker pada kecepatan 120 rpm untuk produksi enzim AbfA. Enzim AbfA yang akan digunakan dalam penelitian ini adalah enzim AbfA ekstraseluler dan cell associated. 


\section{Penentuan Gula Pereduksi dengan Metode DNS}

Sampel (t15 DNS) disiapkan dengan mereaksikan 0,5 $\mathrm{mL}$ enzim dan 0,05 gram substrat (serbuk janur kelapa) dalam tabung reaksi. Kemudian ditambah $2 \mathrm{~mL}$ buffer fosfat pH 6 0,1 M. Campuran diinkubasi pada suhu $70^{\circ} \mathrm{C}$ selama 15 menit. Selanjutnya ditambahkan $0,5 \mathrm{~mL}$ larutan glukosa induk 10 $\mathrm{mg} / \mathrm{mL}$ dan 2,0 $\mathrm{mL}$ pereaksi DNS. Tabung reaksi ditutup dengan alumunium foil, lalu diinkubasi pada suhu $90{ }^{\circ} \mathrm{C}$ selama 15 menit. Kemudian campuran larutan ditambah dengan $1,0 \mathrm{~mL}$ kalium natrium tartrat $40 \%$ dan didiamkan pada suhu ruang selama 20 menit. Selanjutnya, campuran disentrifugasi dengan kecepatan $5000 \mathrm{rpm}$ selama 1 menit. Supernatan diukur absorbansinya pada panjang gelombang $540 \mathrm{~nm}$. Perlakuan yang sama dilakukan pada blanko dan standar (t0 DNS), namun tanpa dilakukan inkubasi. Rincian prosedur di atas ditunjukkan pada Tabel 1 . Perhitungan kadar gula pereduksi yang terbentuk pada waktu inkubasi 15 menit dilakukan secara spektrofotometri UV-Vis dengan metode standar internal.

\section{Penentuan Gula Pereduksi dengan metode NS}

Sampel (t15 NS) disiapkan dengan mereaksikan 0,25 $\mathrm{mL}$ enzim dan 0,05 gram substrat alami janur kelapa dalam tabung reaksi. Kemudian ditambah 2,5 $\mathrm{mL}$ buffer fosfat $\mathrm{pH} 60,1 \mathrm{M}$. Campuran diinkubasi pada suhu $70{ }^{\circ} \mathrm{C}$ selama 15 menit. Selanjutnya ditambahkan $0,5 \mathrm{~mL}$ larutan glukosa induk 10 $\mathrm{mg} / \mathrm{mL}$ dan $0,5 \mathrm{~mL}$ pereaksi Nelson. Tabung reaksi ditutup dengan alumunium foil, lalu diinkubasi pada suhu $100{ }^{\circ} \mathrm{C}$ selama 20 menit. Kemudian campuran larutan didiamkan pada suhu ruang selama 20 menit dan ditambah dengan $0,5 \mathrm{~mL}$ arsen molibdat.

Campuran larutan diencerkan dengan menambahkan akuades 0,75 $\mathrm{mL}$ kemudian dikocok hingga homogen. Selanjutnya, campuran disentrifugasi dengan kecepatan $5000 \mathrm{rpm}$ selama 1 menit. Supernatan diukur absorbansinya pada panjang gelombang 540 nm. Perlakuan yang sama dilakukan pada blanko dan standar (t0 NS), namun tanpa dilakukan inkubasi. Rincian prosedur di atas ditunjukkan pada Tabel 2. Perhitungan kadar gula pereduksi yang terbentuk pada waktu inkubasi 15 menit dilakukan secara spektrofotometri UV-Vis dengan metode standar internal.

Tabel 1. Rincian Komponen dalam Penentuan Gula Pereduksi dengan Metode DNS

\begin{tabular}{lccc}
\hline Komponen & $\begin{array}{c}\text { Blanko } \\
\text { DNS }\end{array}$ & $\begin{array}{c}\text { Standar } \\
\text { t0 DNS }\end{array}$ & $\begin{array}{c}\text { Sampel } \\
\text { t15 DNS }\end{array}$ \\
\hline Enzim (mL) & 0,5 & 0,5 & 0,5 \\
Substrat (g) & 0,05 & 0,05 & 0,05 \\
$\begin{array}{l}\text { Buffer pH 6 } \\
\text { (mL) }\end{array}$ & 2,5 & 2,0 & 2,0 \\
$\begin{array}{l}\text { Glukosa } 10 \\
\text { mg/mL) }\end{array}$ & 0 & 0,5 & 0,5 \\
$\begin{array}{l}\text { Pereaksi } \\
\text { DNS (mL) }\end{array}$ & 2,0 & 2,0 & 2,0 \\
$\begin{array}{l}\text { Inkubasi } \\
\text { (menit) }\end{array}$ & 0 & 0 & 15 \\
\hline
\end{tabular}

Tabel 2. Rincian Komponen dalam Penentuan Gula Pereduksi dengan metode NS

\begin{tabular}{|c|c|c|c|}
\hline Komponen & $\begin{array}{l}\text { Blanko } \\
\text { NS }\end{array}$ & $\begin{array}{l}\text { Standar } \\
\text { t0 NS }\end{array}$ & $\begin{array}{l}\text { Sampel } \\
\text { t15 NS }\end{array}$ \\
\hline Enzim (mL) & 0,25 & 0,25 & 0,25 \\
\hline Substrat (g) & 0,05 & 0,05 & 0,05 \\
\hline $\begin{array}{l}\text { Buffer pH } 6 \\
(\mathrm{~mL})\end{array}$ & 3,0 & 2,5 & 2,5 \\
\hline $\begin{array}{l}\begin{array}{l}\text { Glukosa } \\
(\mathrm{mg} / \mathrm{mL})\end{array} \\
10\end{array}$ & 0 & 0,5 & 0,5 \\
\hline $\begin{array}{l}\text { Pereaksi } \\
\text { Nelson (mL) }\end{array}$ & 0,5 & 0,5 & 0,5 \\
\hline $\begin{array}{l}\text { Arsen } \\
\text { molibdat } \\
(\mathrm{mL})\end{array}$ & 0,5 & 0,5 & 0,5 \\
\hline $\begin{array}{l}\text { Aquades } \\
(\mathrm{mL})\end{array}$ & 0,75 & 0,75 & 0,75 \\
\hline $\begin{array}{l}\text { Inkubasi } \\
\text { (menit) }\end{array}$ & 0 & 0 & 15 \\
\hline
\end{tabular}

\section{Perhitungan Aktivitas Enzim}

Absorbansi hasil pengukuran

dikorelasikan dengan kadar gula pereduksi atau diasumsikan sebagai glukosa yang dihasilkan terhadap waktu inkubasi merupakan aktivitas enzim tersebut. Aktivitas enzim AbfA dinyatakan dalam satuan Unit per $\mathrm{mL}$, dengan satu Unit (U) enzim didefinisikan sebagai jumlah enzim yang dibutuhkan untuk menghasilkan 1,0 $\mu$ mol glukosa yang dihasilkan tiap menit pada kondisi pengujian (suhu $70{ }^{\circ} \mathrm{C}$ dan $\mathrm{pH}$ 6,0). Perhitungan aktivitas enzim AbfA diperoleh dari kadar gula pereduksi yang terbentuk pada waktu inkubasi reaksi enzimatis selama 15 menit dan ditunjukkan dengan persamaan berikut. 
1 Unit $=1 \mu \mathrm{mol}$ glukosa/menit

$=\frac{0,001 \mathrm{mmol} x 180 \mathrm{~g} / \mathrm{mol}}{\text { menit }}=0,18 \mathrm{mg}$ glukosa $/$ menit

Aktivitas enzim $(\mathrm{U} / \mathrm{ml})=$

$\frac{x \mathrm{mg} \text { glukosa }}{\frac{0,18 \mathrm{mg} \text { glukosa/menit }}{\mu \mathrm{mol} / \mathrm{menit}} . \text { Volume enzim } . \text { waktu inkubasi }}$
$=$
$\frac{x \mathrm{mg} \text { glukosa }}{0,18 \mathrm{mg} \text { glukosa .Volume enzim } .15} \times \frac{\mu \mathrm{mol} \text { glukosa }}{\mathrm{mL} \text { menit }}$

\section{HASIL DAN PEMBAHASAN}

Metode DNS dan metode NS merupakan dua metode yang sering digunakan dalam penentuan gula pereduksi seperti glukosa, galaktosa, laktosa dan maltosa. Prinsip metode DNS adalah gula pereduksi akan bereaksi dengan reagen DNS membentuk senyawa asam 3-amino-5-nitrosalisilat yang berwarna kuning kecoklatan. Sedangkan metode NS memiliki prinsip yaitu gula pereduksi mereduksi ion $\mathrm{Cu}^{2+}$ menjadi ion $\mathrm{Cu}^{+}$, kemudian ion $\mathrm{Cu}^{+}$akan mereduksi senyawa arsen molibdat membentuk kompleks berwarna biru kehijauan. Pengukuran absorbansi dilakukan pada panjang gelombang yang sama, yaitu $540 \mathrm{~nm}$.

Perbandingan metode DNS dan metode NS dalam pengukuran aktivitas enzim AbfA pada penelitian ini dilakukan pada kondisi optimum enzim ( $\mathrm{pH}$ 6, suhu $70^{\circ} \mathrm{C}$ ) (Wirajana, 2016). Perbandingan aktivitas enzim AbfA dengan metode DNS dan metode NS terdapat pada Tabel 3.

Tabel 3 menunjukkan bahwa enzim AbfA yang diukur dengan metode DNS memiliki aktivitas lebih tinggi jika dibandingkan dengan aktivitas enzim yang diukur dengan metode NS, karena volume enzim yang digunakan pada metode DNS dua kali lebih besar daripada metode NS $(0,50 \mathrm{~mL}$ dalam metode DNS dan 0,25 dalam metode NS). Penggunaan volume enzim yang berbeda karena alasan teknis. Prosedur pengukuran aktivitas enzim dengan metode NS mengharuskan perbandingan antara pereaksi NS dengan glukosa adalah 1:1, dan enzim yang digunakan harus lebih sedikit dari pereaksi agar semua gula pereduksi hasil hidrolisis substrat janur kelapa dapat bereaksi sempurna dengan pereaksi NS. Apabila enzim yang ditambahkan lebih banyak daripada pereaksi NS, maka kemungkinan tidak semua gula pereaksi yang terbentuk dapat terukur absorbansinya. Sehingga, apabila volume enzim yang digunakan sama, maka kemungkinan aktivitas enzimnya tidak jauh berbeda. Menurut Gusakov (2011) metode DNS yang digunakan dalam penentuan aktivitas selulase memberikan nilai aktivitas 40-50\% lebih tinggi dibandingkan metode NS.

Tabel 3. Perbandingan aktivitas enzim AbfA dengan metode DNS dan metode NS

\begin{tabular}{cccc}
\hline Metode & Ulangan & $\begin{array}{c}\text { Aktivitas } \\
\text { AbfA } \\
\text { (U/mL) }\end{array}$ & $\begin{array}{c}\text { Aktivitas } \\
\text { AbfA rata- } \\
\text { rata } \\
\text { (U/mL) }\end{array}$ \\
\hline \multirow{3}{*}{ DNS } & I & 1,0385 & $0,6114 \pm$ \\
& III & 0,4052 & 0,3699 \\
& I & 0,3904 & \\
NS & II & 0,3704 & $0,3679 \pm$ \\
& III & 0,3526 & 0,0142 \\
\hline
\end{tabular}

Aktivitas enzim yang ditentukan dengan metode DNS pada penelitian ini diperoleh sebesar 0,6114 $\pm 0,3699 \mathrm{U} / \mathrm{mL}$, sedangkan aktivitas enzim yang diukur dengan metode NS adalah 0,3679 $\pm 0,0142 \mathrm{U} / \mathrm{mL}$. Hasil tersebut menunjukkan bahwa standar deviasi dari aktivitas enzim dengan metode DNS jauh lebih besar daripada standar deviasi aktivitas enzim dengan metode NS. Standar deviasi menunjukkan kedekatan suatu nilai dengan rata-ratanya dan dapat digunakan untuk menentukan baik buruknya representasi dari keseluruhan data. Nilai standar deviasi yang kecil menunjukkan bahwa representasi data baik karena semua data mendekati nilai ratarata, begitu pula sebaliknya. Aktivitas enzim yang diperoleh dengan metode NS lebih teliti dibandingkan dengan aktivitas enzim dengan metode DNS.

Apabila dibandingkan dari segi linearitas, kurva kalibrasi larutan standar metode DNS lebih linear dibandingkan metode NS (Gambar 1 dan 2). Linearitas ini ditunjukkan oleh nilai koefisien determinasi $\left(\mathrm{R}^{2}\right)$ yang terdapat dalam masing-masing kurva. Koefisien determinasi kurva larutan standar dengan metode DNS 0,9846, sedangkan koefisien determinasi kurva larutan standar dengan metode NS adalah 0,8905. Nilai $\mathrm{R}^{2}$ ini menunjukkan bahwa pengaruh 
faktor pengganggu lebih besar terdapat pada metode NS $( \pm 11 \%)$ dibandingkan metode DNS $( \pm 2 \%)$. Menurut Bruell and Saddler (1985), metode NS dikenal lebih sensitif terhadap faktor pengganggu, sehingga dapat menurunkan nilai aktivitas enzim. Metode NS telah diketahui memberikan nilai aktivitas yang lebih rendah dibandingkan DNS.

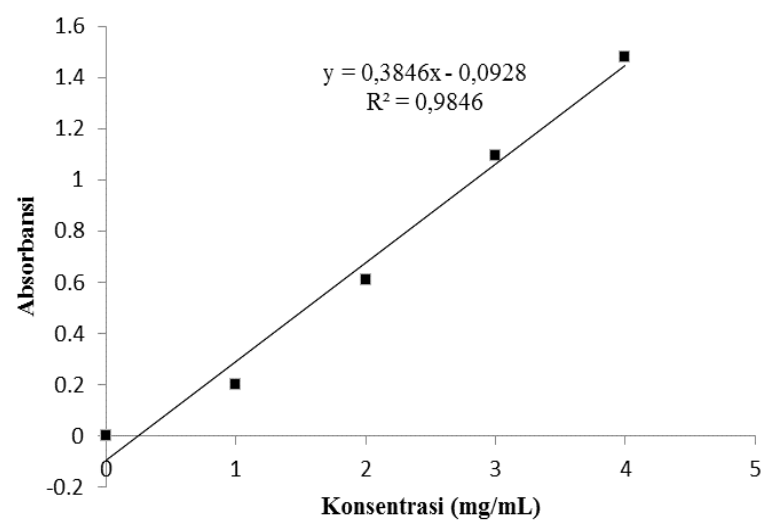

Gambar 1. Kurva larutan standar glukosa dengan metode DNS.

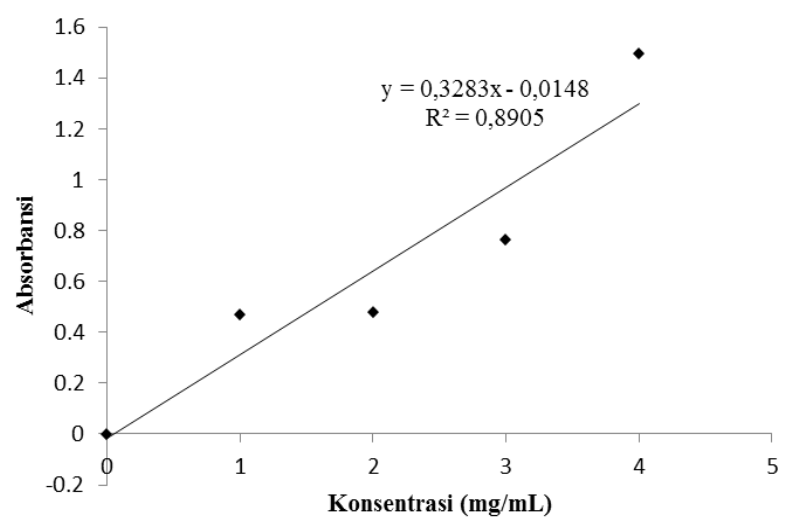

Gambar 2. Kurva larutan standar glukosa dengan metode NS.

Metode DNS lebih banyak digunakan dalam pengukuran aktivitas enzim yang produknya berupa gula pereduksi, meskipun harga pereaksinya relatif lebih mahal dibandingkan pereaksi dalam metode NS. Hal ini karena reagen yang digunakan dalam metode NS bersifat lebih toksik dan lebih sensitif terhadap faktor pengganggu dibandingkan pada metode DNS (Bailey, 1992). DNS memiliki tingkat ketelitian lebih tinggi sehingga dapat mengukur gula pereduksi dalam konsentrasi kecil. Dalam preparasi pembuatannya, metode DNS lebih mudah dan lebih praktis dibandingkan metode NS (Irawati, 2016).

Perbandingan metode DNS dan metode NS yang ditinjau dari nilai aktivitas enzim, standar deviasi, linearitas kurva standar dan preparasi pereaksi menunjukkan bahwa kedua metode ini memiliki kelebihan dan kekurangan masing-masing. Kedua metode ini dapat digunakan dalam pengukuran konsentrasi gula pereduksi dalam penentuan aktivitas enzim AbfA. Namun, apabila ditinjau dari segi kestabilan pereaksi, metode NS lebih disarankan karena pereaksi ini dapat disimpan dalam jangka waktu lama tanpa mengubah substansi yang ada dalam pereaksi tersebut.

\section{SIMPULAN DAN SARAN}

\section{Simpulan}

Berdasarkan hasil penelitian disimpulkan bahwa penentuan aktivitas enzim Abf A dengan metode NS lebih teliti (standar deviasi yang jauh lebih kecil, 0,3679 $\pm 0,0142$ $\mathrm{U} / \mathrm{mL}$ ) dibandingkan dengan metode DNS $(0,6114 \pm 0,3699 \mathrm{U} / \mathrm{mL})$, namun kurva kalibrasi larutan standar metode DNS lebih linear dibandingkan dengan metode NS.

\section{Saran}

Penentuan aktivitas enzim AbfA dengan substrat janur kelapa perlu dilakukan pada berbagai variasi kondisi $\mathrm{pH}$, suhu, waktu inkubasi, konsentrasi substrat dan konsentrasi enzim dengan metode DNS dan metode Nelson-Somogyi untuk diperoleh kondisi yang optimum.

\section{UCAPAN TERIMA KASIH}

Penulis menyampaikan terima kasih kepada Koordinator Program Studi Kimia Fakultas MIPA dan Kepala UPT Laboratorium Forensik Universitas Udayana beserta seluruh staf atas bantuan dan fasilitas yang diberikan dalam pelaksanaan penelitian ini.

\section{DAFTAR PUSTAKA}

Bailey, M.J., Biely, P., and Poutanen, K., 1992, Interlaboratory Testing of Methods for Assay Of Xylanase Activity, J. of Biotechnol., 23: 257-270. 
Perbandingan Metode Uji Gula Pereduksi dalam Penentuan Aktivitas $\alpha$-L-Arabinofuranosidase dengan Substrat Janur Kelapa (Cocos nucifera) (Y. H. Pratiwi, O. Ratnayani, dan I N. Wirajana)

Bruell, C. and Saddler, J. N., 1985, Enzyme Microbiology Technol., J. Biochemistry, 7: 327-332.

Gusakov, A.V., Kondratyeva, E.G., and Sinitsyn, A.P., 2011, Comparison of Two Methods for Assaying Reducing Sugars in the Determination of Carbohydrase Activities, International Journal of Analytical Chemistry, 1-4.

Irawati, R., 2016, Karakterisasi pH, Suhu dan Konsentrasi Substrat pada Enzim Selulase Kasar yang Diproduksi oleh Bacillus circulans. Skripsi, Universitas Islam Negeri Maulana Malik Ibrahim, Malang.

Liao, Hanpeng, Li, Shuixian, Wei, Zhong, Shen, Qirong dan Xu, Yangchun, 2014, Insights Into High-Efficiency Lignocellulolytic Enzyme Production by Penicillium oxalicum GZ-2 Induced by a Complex Substrate, Biotechnology For Biofuels, 7:162.

Patel, H., Chapla, D., Divecha, J., dan Shah, A., 2015, Improved Yield of $\alpha$-LArabinofuranosidase by Newly Isolated Aspergillus niger ADH-11 and Synergistic Effect of Crude Enzyme on
Saccharification of Maize Stover, Bioresources and Bioprocessing, 2: 11.

Puspaningsih, N. N. T., 2004, Pencirian Enzim Xilanolitik dan Kloning Gen Penyandi Xilosidase dari Bacillus thermoleovorans IT-08, Disertasi, Institut Pertanian Bogor.

Somogyi, M. J., 1952, Notes on Sugar Determination, Journal of Biolological Chemistry, 195: 19-23.

Tirono dan Ali, 2011, Efek Suhu Pada Proses Pengarangan Terhadap Nilai Kalor Arang Tempurung Kelapa (Coconut Shell Charcoal), Universitas Islam Negeri, Malang.

Wang, N.S., 2009, Biochemical Engineering Laboratory: Glucose Assay by Dinitrosalicylic Colorimetric Method, University of Maryland, Maryland.

Wirajana, I.N., Kimura, T., Sakka, K., Wasito, E.B., Kusuma, E.K., \& Puspaningsih, N.N.T., 2016, Secretion of Geobacillus thermoleovorans IT-08 $\alpha$-L-Arabinofuranosidase (AbfA) in Saccharomyces cerevisiae by Fusion with HM-1 Signal Peptide, Procedia Chemistry 18: 69 74. 